2013

\title{
Wisdom is Thrown into Jail: Using Therapeutic Jurisprudence to Remediate the Criminalization of Persons with Mental Illness
}

Michael L. Perlin

New YorkLaw School, michael.perlin@nyls.edu

Follow this and additional works at: https://digitalcommons.nyls.edu/fac_articles_chapters

3 Part of the Criminal Procedure Commons, Disability Law Commons, Law and Psychology Commons, and the Law Enforcement and Corrections Commons

\section{Recommended Citation}

Perlin, Michael L., "Wisdom is Thrown into Jail: Using Therapeutic Jurisprudence to Remediate the Criminalization of Persons with Mental Illness" (2013). Articles \& Chapters. 944.

https://digitalcommons.nyls.edu/fac_articles_chapters/944 


\title{
"WISDOM IS THROWN INTO JAIL": USING THERAPEUTIC JURISPRUDENCE TO REMEDIATE THE CRIMINALIZATION OF PERSONS WITH MENTAL ILLNESS
}

\author{
Michael L. Perlin*
}

INTRODUCTION 343

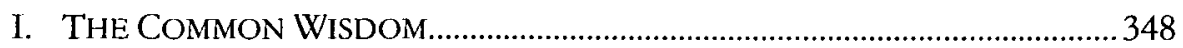

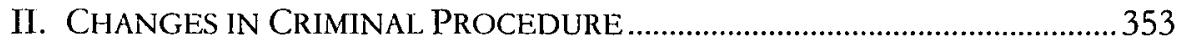

A. The Shrinking of the Insanity Defense.................................................353

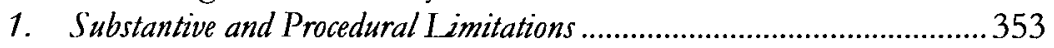

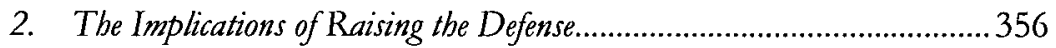

3. The Length of Post-acquittal Commitments ..............................................357

B. The Perils of Raising the Incompetency Status....................................358

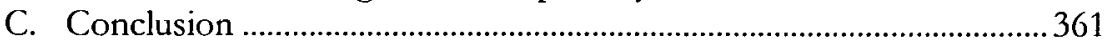

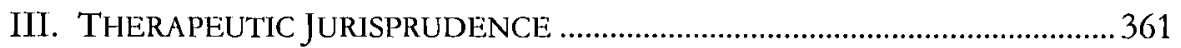

IV. Contextualizing Criminal Justice And Mental Disability......364

\section{INTRODUCTION}

The common wisdom is that there are twin, related villains in the saga of the "criminalization of persons with mental illness": the drastic elimination of psychiatric hospital beds in the 1970s and the 1980s as a result of the "civil rights revolution;" and the "failure" of the deinstitutionalization movement.1 Both of these explanations are superficially appealing, but neither is correct. The reduction in state hospital beds - which began in 1954 when the first generation of antipsychotic drugs such as Thorazine were first made available 2 - was the logical outcome of revelations that state hospital systems were being overused inappropriately and in ways that consigned tens of thousands of citizens to the equivalent of lifetime sentences in substandard, dangerous pris-

* Director of the International Mental Disability Law Reform Project and the Online Mental Disability Law Program; Professor, New York Law School. J.D. 1969, Columbia Law School; A.B. 1966, Rutgers University. The author wishes to thank Alison Lynch for her excellent research assistance.

1. See generally Samuel R. Bagenstos, The Past and Future of Deinstitutionalization I itigation, 34 Cardozo L. Rrv. 1, 3-12 (2012); Michael L. Perlin, Competency, Deinstitutionalization, and Homelessness: A Story of Marginalization, 28 Hous. L. Rrv. 63 (1991).

2. See, e.g., Jonathan Fish, Overcrowding on the Ship of Fools: Health Care Reform, Psychiatry, and the Uncertain Future of Normality, 11 HOUS. J. HEALTH L. \& POL'Y 181, 198-99 (2012); Bernard E. Harcourt, Reducing Mass Incarceration: I essons from the Deinstitutionalization of Mental Hospitals in the 1960 s, 9 OHIO ST. J. Crim. L. 53, 65 (2011). 
on-like facilities ${ }^{3}$ (characterized by an expert witness, without rebuttal, in discussing a facility that was at the heart of a famous law reform case, as "Dachau, without ovens") ${ }^{4}$ Such facilities often provided little more than custody and often exacerbated the underlying psychosocial disabilities that led to institutionalization in the first place. 5 The "failures" of deinstitutionalization were never with the theory of deinstitutionalization, but instead with the political cowardice of state and federal legislatures in their failures to appropriately fund and support community living arrangements for persons with mental disabilities, even those (perhaps, especially those) with serious psychiatric disabilities. ${ }^{6}$

At the same time, virtually all valid and reliable behavioral research taught us that rehabilitation - by any reasonable definition of that term - was impossible in the large public institutions that are so nostalgically referenced in so much of the "bring back the good old days" literature. ${ }^{7}$ Beyond this, over a decade ago, the U.S. Supreme Court's decision in Olmstead v. L.C. 8 ruled that the Americans with Disabilities Act mandated that patients had a right to treatment in an integrated community setting as opposed to an unnecessarily segregated state hospital, stressing that "[u]njustified isolation . . . is properly regarded as discrimination based on disability."

But this is nothing new to those of us who have spent our careers thinking about these issues. And the fact remains that, in spite of all the research, the litigation, the advocacy, and the public interest, the percentage of persons with mental illness in jails and prisons appears to be increasing dramatically ${ }^{10}$

3. See generally Michael L. Perlin, "Abandoned I ove": The Impact of Wyatt $v$. Stickney an the Intersection Between International Human Rights and Domestic Mental Disability I aw, 35 L. \& PSYCHOI.. REV. 121 (2011).

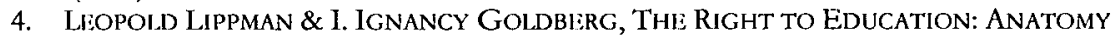

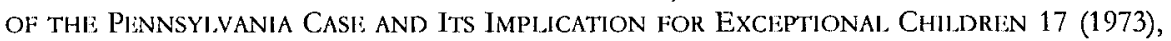
quoted in Perlin, supra note 1 , at 100 n. 215. The reference was to the Pennhurst State School in suburban Philadelphia, PA. See generally Pennhurst State Sch. \& Hosp. v. Halderman, 451 U.S. 1 (1981).

5. See Youngberg v. Romeo, 457 U.S. 307, 327 (1982) (Blackmun, J., concurring) (urging adoption of a "non-deterioration" standard (that an individual committed to a facility for persons with mental disabilities is entitled to "such training as is reasonably necessary to prevent a person's pre-existing self-care skills from deteriorating because of his commitment')). On how this concurrence has been expanded upon in subsequent institutional rights litigation, see 2 Michalil L. Perlin, Mental. Disability Law: Civil. And Criminal., at 111-17 (2d ed. 1999).

6. See Perlin, supra note 1, at 94-96.

7. See, e.g., Joanmarie Ilaria Davoli, No Room at the Inn: How the Federal Medicaid Program Created Inequities in Psychiatric Hospital Access for the Indigent Mentally Ill, 29 AM. J.L. \& MED. 159, 180 (2003) ("The failure of deinstitutionalization to improve treatment for the mentally ill is reminiscent of the failure of state-run psychiatric institutions to deliver humane, effective treatment and care over an extended period of time.").

8. 527 U.S. 581 (1999).

9. Id. at 582,597 .

10. We know virtually nothing about the percentages in the $1940 \mathrm{~s}$ and $1950 \mathrm{~s}$; to the best of my knowledge, there is no data available on that question. 
for reasons somehow related to deinstitutionalization and the enforcement of the civil rights of patients. It is a truism that (depending on where you live) Rikers Island or the Cook County House of Detention or the Los Angeles County Jail is the "largest mental health facility in the nation." 11 Data tells us that there are three times as many individuals incarcerated in prison as institutionalized in mental hospitals and it is estimated that, in the United States, $14.5 \%$ of male adults in prisons and jails have a mental illness, as do $31 \%$ of female adults ${ }^{12}$ - a rate of two to four times that of the general population. ${ }^{13}$ And, importantly, prisoners with mental illness are more likely to violate prison rules leading to disciplinary hearings, inappropriate sanctions, and segregation. ${ }^{14}$ It is clear that sometbing has happened (and continues to happen), but I am not convinced at all that the common wisdom about it is anywhere nearly accurate.

The questions that I wish to address today are these: What are we missing, and what, if anything, can/should we do? But first, let me offer an idea to which we have failed to pay any attention in this context and suggest that it may be a major "hidden culprit" in this entire discussion. An idea that is based significantly on my own professional background, from the thirteen years that I was a "real lawyer" before I became a professor. I spent three years as a Deputy Public Defender in Trenton, New Jersey, and eight years as director of the New Jersey Division of Mental Health Advocacy (this was between 1971 and 1982 - not an unimportant factor in this story). A significant portion of my caseload involved the representation of persons with mental illness who had been charged with crime, often with serious crime.

11. See, e.g., Gregory L. Acquaviva, Mental Health Courts: No I onger Experimental, 36 Sr:TON HAI. L. RI:v. 971, 978 (2006) (observing that, "in 1992, the Los Angeles County jail became the nation's largest mental institution, with Cook County Jail, Illinois, and Riker's Island, New York, as second and third respectively."). Judges concur with this finding. See Judge Stephen S. Goss, Mental Health Court Programs in Rural and Nonaffluent Jurisdictions, 33 CRIM. JUST. RIiv. 405, 405 (2008) ("Our jails have become the de facto mental health treatment centers for many persons.").

12. Henry Steadman et al., Prevalence of Serious Mental Illness Among Jail Inmates, 60 PSYCHIATRIC Si:RVS. 761, 761 (2009). On the strong causal relationship between incarceration and major depressive disorder and bipolar disorder, see Jason Schnittker et al., Out and Down: Incarceration and Psychiatric Disorders, 53 J. Hı:AI.TH \& SOC'ı. Bı:HAV. 448 (2012).

13. See generally Jamie Fellner, $A$ Corrections Quandary: Mental Illness and Prison Rules, 41 Harv. C.R.-C.L. L. RI:V. 391 (2006); Christina Canales, Prisons: The New Mental Healtb System, 44 CONN. L. Rivv. 1725 (2012); William Narrow et al., Revised Prevalence of Estimates of Mental Disorders in the United States, 59 ARCH. GIiN. PSYCHIATRY 115 (2002).

14. Fellner, supra note 13, at 395-96. See also Henry Steadman, Foreword to RisDON N.

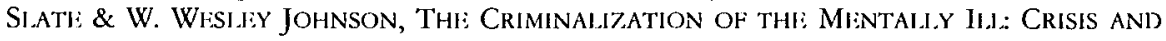
OPPORTUNITY FOR THI: JUSTICI: SYSTIM xiii (2008) (rates of major depression of male jail and prison inmates are four times that of the general population, and of female inmates, ten times; rates are ten times higher for incidences of bipolar disorders). 
I have recounted elsewhere the story of how, soon after the U.S. Supreme Court decided Jackson v. Indiana (thus "creating" modern mental health law), ${ }^{15}$ I filed a class action suit in New Jersey, Dixon $v$. Cabill, to implement Jackson (when I was but a rookie Public Defender), resulting in a court ruling that the indefinite incarceration of individuals in the Vroom Building - New Jersey's "maximum security facility for the criminally insane"16 - violated Jackson and that each institutionalized individual had a right to an individual hearing. "This was in 1973, and we quickly discovered cases of individuals who had been awaiting trial since 1963, 1953, 1948, and, in one case, 1928," and, when the dust settled, "the courts ultimately found that 185 of our 225 clients had been illegally detained." 17 The international publicity that flowed from this case led to the creation of the Division of Mental Health Advocacy in the New Jersey Department of the Public Advocate, and regularized the representation of persons being civilly committed against their will and those seeking release from institutionalization. This was all, of course, part and parcel of the mental health advocacy "movement" of the 1970s, an outgrowth of the greater turn to "public interest law" at this time in our nation's legal history. ${ }^{18}$

But, a series of developments in the 1980s changed the contours of this legal landscape, reflecting some "disencbantment on the part of the public ... and ... federal courts with the notion of vastly expanding the civil rights and civil liberties of persons with mental disabilities." 19 Subsequently, in that numerically-small, but well-publicized (often over-publicized) universe of cases in which persons with serious mental disabilities are charged with serious crimes, ${ }^{20}$ raising mental status defenses - never a great option for a criminal defense lawyer - became a much riskier and potentially-catastrophic option. ${ }^{21}$ Although there has been a robust literature on the meaning and significance of these changes in criminal procedure, to the best of my knowledge, no one

15. 406 U.S. 715,738 (1972) ("At the least, due process requires that the nature and duration of commitment bear some reasonable relation to the purpose for which the individual is committed. $[\mathrm{A}]$ person charged by a State with a criminal offense who is committed solely on account of his incapacity to proceed to trial cannot be held more than the reasonable period of time necessary to determine whether there is a substantial probability that he will attain that capacity in the foreseeable future."). See Michael L. Perlin, 'Justice's Beautiful Face": Bob Sadoff and the Redemptive Promise of Therapeutic Jurisprudence, 40 J. PSYCHIATRY \& L. 265, 278 n. 2 (2012) (discussing Jackson's impact).

16. See Michael L. Perlin, "Half-Wracked Prejudice I eaped Forth": Sanism, Pretextuality, and Why and How Mental Disability I anv Developed as It Did, 10 J. CoNTEMP. LlaGAl Issurs 3, 7 (1999).

17. Michael L. Perlin, "May You Stay Forever Young": Robert Sadoff and the History of Mental Health law, 33 J. AMER. ACAD. Psychiatry \& L. 236, 237 (2005).

18. See 2 PERLIN, supra note 5, at 6-20 (discussing reasons for the expansion at this point in time of the rights of persons institutionalized because of mental disabilities).

19. Id. at 22 .

20. See, e.g., Joanmarie Ilaria Davoli, Pbysically Present, Yet Mentally Absent, 48 U. LouISVILLLE L. Riv. 313, 315 (2009).

21. See generally Michaie. L. Perlin, The Jurisprudince of thi: Insanity Definse 1 (1994). 
yet has considered them in the context of the issue addressed in this paper the criminalization of persons with mental illness. This will be a focus of my paper.

First, in Part I, I will address the "common wisdom" explanations, and explain why I find them wanting. Next, in Part II, I will consider the relevant major changes in criminal procedure over the past thirty years that have contributed significantly to the problems we face. Some of these changes include: (1) the narrowing of the insanity defense, (2) the constitutional sanctioning of lengths of commitment for insanity acquittees that are far longer than the maximum sentences for the underlying charged offenses, (3) Supreme Court decisions making it less likely that jurors will accept the insanity defense, (4) the extended sentences faced by defendants who unsuccessfully raise the insanity defense, (5) the enlarged use of involuntary antipsychotic medication in efforts to make incompetent defendants competent to stand trial, and (6) the failure of most states to comply with the now-forty-year-old mandate of Jackson $v$. Indiana. In Part III, I will look at the potential use of therapeutic jurisprudence as a tool to deal with the current state of affairs. In Part IV, I will conclude with some policy recommendations in an effort to remediate the current problems, including the need to train lawyers on the issues I discuss in this paper and the role of mental health courts as a potentially ameliorating partial-solution.

My title comes from Bob Dylan's song, Political World, a song that he, alas, has not sung since February 1991.22 The lyric comes from this couplet:

We live in a political world

Wisdom is thrown into jail

It rots in a cell, is misguided as hell

Leaving no one to pick up a trail ${ }^{23}$

Over a decade ago, I concluded that this line "captured the entire insanity defense debate." 24 The "worldview" of Political World is "dangerous and suspicious," filled with "anxiety and despair," and warns of "spiritual death." 25 It is, in the words of one critic, "Bob's commentary on the state of the fallen

22. See generally, e.g., Michael L. Perlin, "I ife Is In Mirrors, Death Disappears": Giving I ife to Atkins, 33 N. Mix. L. Riv. 315 (2003) [hereinafter Perlin, Death Disappear;; Michael L. Perlin, Myths, Realities, and the Political World: The Anthropology of Insanity Defense Attitudes, 24 Bul.L. AM. ACAD. Psychiatry L. 5 (1996); Michael L. Perlin, "Big Ideas, Images and Distorted Facts": The Insanity Defense, Genetics, and the Political World, in Ginitics And Criminal.ITY: ThI: POTINTIAI. MisuSi: OF SCIINTIFIC INFORMATION IN COURT 37 (Jeffrey R. Botkin et al. eds., 1999) (hereinafter Perlin, Big Ideas). I discuss the Ob Merg! album (of which Political World is the opening track) in Michael L. Perlin, Blood on the Cusp, 1 Montague Striest 13 (2009).

23. Bob Dylan, Political World, on OH Mrrcy (Sony Music Entertainment Inc. 1989).

24. Perlin, Big Ideas, supra note 22, at 39.

25. Olivier Traglik, Kliys to the Rain: Thli Difinitivi: Bob DYlan Encycioplidia 493 (2004). 
world we live in."26 I have characterized it elsewhere as "pretty existential."27 By continuing to mouth banal platitudes about the alleged villains in the scenario that we are discussing today, we continue to throw wisdom, along with uncounted persons with mental disabilities into jail.

\section{THE COMMON WISDOM}

Over twenty years ago, I summarized the common wisdom about deinstitutionalization in the following way, and little has happened in the intervening years to lead me to change what I then said:

The story goes something like this: nurtured by radical psychiatrists (such as Thomas Szasz and R.D. Laing), spurred on by politically-activist organizations pushing egalitarian social agendas (such as the ACLU), a cadre of brilliant but diabolical patients' rights lawyers dazzled sympathetic and out-of-touch judges with their legal legerdemain - abetted by wooly-headed social theories, inapposite constitutional arguments, some ohmy-god worst-case anecdotes about institutional conditions, and a smattering of "heartwarming successful [deinstitutionalization] cases"- as a result of which courts entered orders "emptying out the mental institutions" so that patients could "die with their rights on." When cynical bureaucrats read the judicial handwriting on the hospital walls, they then joined the stampede, and the hospitals were thus emptied. Ergo deinstitutionalization. Ergo homelessness. Endgame. ${ }^{28}$

I said then that that story was "all wrong. Dead wrong. Obscenely wrong." 29 And, in spite of a tsunami of polemic seeking to rectify the position that I reject, I still believe, perhaps more strongly than ever, that the story, indeed, is wrong. ${ }^{30} \mathrm{I}$ cast my lot here with Professor Sam Bagenstos who argues, persuasively, that "deinstitutionalization has been a success in many significant respects," 31 pointing out how many facilities - including the one

26. See Perlin, Death Disappears, supra note 22, at 316.

27. Michael L. Perlin, Tangled Up In L aw: The Jurisprudence of Bob Dylan, 38 ForD. URB. L.J. 1395,1408 (2011).

28. Michael L. Perlin, Book Review, 8 N.Y.L. SCH. J. Hum. RTs. 557, 559 - 60 (1991) (reviewing ANN Braden Johnson, OUT OF Bisdam: The TruTH About DEINSTITUTIONAIIZATION (1990)).

29. Id. at 560 .

30. See Olmstead, 527 U.S. at 609 (Kennedy, J., concurring in judgment). "A leading critic, Dr. E. Fuller Torrey, described its results as 'a psychiatric Titanic' - an evocative phrase quoted with approval by two Supreme Court justices - and as 'one of the great social disasters of recent American history." Bagenstos, supra note 1, at 2 (quoting E. FULLER TORRIEY, OUT OF THE Shadows: Confronting Amirica's Mintal. Iil.niss Crisis 11 (1997)). See also Robert Weisberg, Restorative Justice and the Danger of "Community," 2003 UTAH L. REv. 343, 364 (2003) ("It is now an axiom that deinstitutionalization caused the contemporary epidemic of homelessness for the mentally ill.").

31. Bagenstos, supra note 1 , at 7 . See also id. at 50: 
described as "Dachau without ovens" 32 - had been closed in the aftermath of the early wave of patients' rights litigation. He adds:

To be sure, we could solve the problem of homelessness among people with psychiatric disabilities by simply institutionalizing them for the long term. But other policies could solve that problem just as well--notably supportive housing, in which individuals obtain tenancy in apartments linked with supportive services. And yet, as homelessness was increasing in the 1980s, the federal and state governments were cutting Supplemental Security Income (SSI) and housing assistance-the very programs that could pay for community-based housing for people with psychiatric disabilities. The indictment of deinstitutionalization, as opposed to the failure to invest in community-based services and supports, does not rest on an empirical determination of what happened in the world so much as on a normative premise that institutionalization is preferable to community-based housing and supports. Given the undoubted harms of long-term institutionalization for people with psychiatric disabilities, and the viability of evidence-based community services ... there is no good reason to prefer institutionalization as the solution to the homelessness problem among people with psychiatric disabilities. ${ }^{33}$

But deinstitutionalization is seen as the villain and criminalization as the inevitable by-product. ${ }^{34}$ Never mind that there is empirical evidence that, in

I hope I have shown that the past of deinstitutionalization litigation was, in key respects, far more successful than most observers acknowledge. The limits of that success were very real, though: although deinstitutionalization advocates succeeded in closing the front doors of large state institutions so that few new people with developmental or psychiatric disabilities came in, and in opening the back doors of those institutions so that the vast majority of long-term residents moved out, they were less successful in building a comprehensive system of adequate and appropriate services in the community. That key failure stemmed, I have argued, from two factors: limitations in the legal-doctrinal tools on which deinstitutionalization advocates relied; and a political alignment that created pressures to close institutions without building the communityId. based services that would be necessary to replace them.

32. See generally, e.g., Pennhurst State School or Hospital, 451 U.S. 1 (a case involving the conditions at a state institution for the mentally ill, which has been described by commentators as "Dachau, without ovens." L. LIPPMANN \& I. GoIDBERG, THI: Righ'T TO EDUCATION: Anatomy of thi: Pinnsyivania Casli and its Implication for Exciiptional. Childidin 17 (1973)).

33. Bagenstos, supra note 1, at 11-12. See also, SI ATl: \& JOHNSON, supra note 14, at 27-28.

34. On how this is a "crude explanation," see Betsy Ginsberg, Out with the New, In with the Old: The Importance of Section 504 of the Rehabilitation Ast to Prisoners with Disabilities, 36 FORDHAM UrB. L.J. 713, 719 n. 24 (2009). For a careful analysis of the shortcomings of this explanation, see William H. Fisher, Eric Silver, \& Nancy Wolff, Beyond Criminalization: Toward a Criminologically Informed Framework for Mental Health Policy and Senvices Research, 33 ADMIN. \& POI.'Y MINNTAI. 
the aftermath of litigation, protective measures (such as a statewide "crisis system") can be put in place to minimize the "likelihood that released patients would become involved in criminal behavior." 35 Never mind that "the causal link between deinstitutionalization and criminalization has never been rigorously tested." 36 Never mind that there is substantial valid and reliable empirical evidence that the successful training of police officers (the so-called "Memphis plan") reduces subsequent criminal behavior and arrests in the population in question, ${ }^{37}$-an option made even more urgent in light of the findings of Professor Linda Teplin that the "likelihood of arrest of persons exhibiting signs and symptoms of mental illness [is] $67 \%$ greater [than that] of those who did not appear to be mentally ill." 38 Never mind that "while the proportion of [persons with serious mental illness] in psychiatric institutions fell by 23 percent, the percentage of incarcerated [persons with serious mental illness] increased only 4 percent in the last half of the last century." 39 Never mind that many persons with mental illness are brought to jails rather than

Hialth \& Mental Hi:alth Slizvs. Ri:s. 544, 549 (2006) (calling for a "criminologicallyinformed mental health services and policy perspective").

35. See Bagenstos, supra note 1, at 34 (discussing Settlement Agreement, United States v. Virginia, Civil Action No. 3:12-CV-059 (E.D. Va. Jan. 26, 2012) (The "agreement contains detailed provisions for a statewide crisis system for people with intellectual and developmental disabilities, so that the response to a behavioral or other crisis is not institutionalization or criminalization but instead is an intervention that ensures that the individual can remain successfully in the community.')).

36. Arthur J. Lurigio, Examining Prevailing Beliefs about People with Serious Mental Illness in the Criminal Justice System, 75 FiD. PROBATION 11, 12 (2011).

37. See Michalel L. Pisilin \& Hienry A. Dlugacz, Mintal Hisaith Issuis in Jails and Prisons 31-36 (2006); Deborah Calloway, Using Mindfulness Practice to Work with Emotions, 10 Niv. L.J. 338, 359 n. 77 (2010) (Memphis has a program that "has resulted in reduced injuries and arrests and increased diversion of mentally ill individuals into treatment programs."). Compare Henry J. Steadman, Martha Williams Deane, Randy Borum, \& Joseph P. Morrissey, Comparing Outcomes of Major Models of Police Responses to Mental Health Emergencies, 51 PsYCHIATRIC SERvs. 645,649 (2000) (In jurisdictions that have adopted a Memphis-type approach, the arrest rate is $7 \%$ in cases involving police encounters with persons with mental illness), with Gordon Strauss et al., Psychiatric Disposition of Patients Brought in by Crisis Intervention Team Police Officers, 41 COMm. MiNT. HEAITH J. 223, 224 (2005) (in other jurisdictions, the estimated arrest rate is 20\%). See Slate \& JOHNSON, supra note 14, at 99-100; H. Richard Lamb et al., Mentally Ill Persons in the Criminal Justice System: Some Perspectives, 75 PsYCHIATRIC Q. 107, 116 (2004).

38. Linda A. Teplin, Keeping the Peace: Police Discretion and Mentally Ill Persons, NAT'L. INST. JUST. J. (July 2000), at 8,12 , available at https://www.ncjrs.gov/pdffiles1/jr000244c.pdf, as discussed in Si.ATI \& JohnSon, supra note 14, at 88. See Peter C. Patch \& Bruce A. Arrigo, Police Officer Attitudes and Use of Discretion in Situations Involving the Mentally Ill, 22 INT'L. J.L. \& PSYCHIATRY 23, 28 (1999) ("In fact, the vast majority of police departments do not provide clear guidelines for interacting with the mentally ill at all.').

39. Lurigio, supra note 36, at 13 (generally citing Richard Frank \& Shiskry Glitid, mintal Hialth POlicy in THE United Statlis sinCe 1950: Bettis but Not Whil. 1 (2006)). 
mental hospitals in the first place $e^{40}$ because of how much more time-consuming mental hospital "drop offs" are and for a variety of other reasons. ${ }^{41}$ Never mind that the evidence is crystal-clear that "people with mental illness 'engage in offending and other forms of deviant behavior not because they have a mental disorder but because they are poor," 42 and that the strongest risk factors for violence "are shared by those with and without mental illness." 43 Never mind that "we know little about the true prevalence of mental illness among offenders throughout all stages of the criminal justice system, or about the extent to which the needs of mentally ill offenders are going unmet."44 Never mind that there is similarly substantial valid and reliable evidence that, if proper screening and placement procedures are employed, every resident of a large inpatient facility could be successfully placed in community settings. ${ }^{45}$

40. These are sometimes referred to as "mercy bookings." See Canales, supra note 13, at 1736 (citing e.g., H. Richard Lamb et al., The Police and Mental Health, 53 Psychiatric Sirrvs. $1266,1267(2002))$.

41. These reasons relate to the work conditions of the police officers involved and to what is perceived as the lack of "supportiveness" of the relevant mental health facilities; and a lack of coordination between the police and mental health professionals, rather than to the acts or the clinical conditions of the apprehended individuals. SI.ATI: \& JOHNSON, supra note 14, at 87-89 (citing, for example, Randy Borum et al., Police Perspectives on Responding to Mentally Ill People In Crisis: Perceptions of Program Effectiveness, 16 Bithav. ScI. \& L. 393 (1998)). See generally Randy Borum et al., Substance Abuse, Violent Behaviors and Police Encounters among Persons with Severe Mental Disorder, 13 J. Contemp. Crim. Just. 236 (1997) [hereinafter Borum et al., Police Encounters]; Virginia G. Cooper et al., Dispositional Decisions with the Mentally Ill: Police Perceptions and Characteristics, 7 Pol.JCI: Q. 295 (2004); J.R. Husted et al., Califomia L aw Enforcement Agencies and the Mentally III Offender, 23 Bui... Am. ACAD. Psychiatry \& L. 315 (1995). See also, Lamb et al., supra note 37.

On how police departments' organizational structures need to be changed so as to better optimize such coordination, see Robert Panzarella \& Justin Alicea, Police Tactics in Incidents with Mentally. Disturbed Persons, 20 Policing: InT'l. J. Pol.icl: Stratigy \& MGMT. 326, 337 (1997). On the need for enhanced collaboration, see Lamb et al., supra note 40. Encouragingly, in one study, over $90 \%$ of police officers reported that they felt mental health training was either fairly or very important. See Marilyn Price, Commentary: The Challenge of Training Police Officers, 33 J. AM. ACAD. PSYCHIAT'RY \& L. 50, 50 (2005) (discussing findings reported in Heidi S. Vermette et al., Mental Health Training for Ian Enforcement Professionals, 33 J. AM. ACAD. PSYCHIATRY \& L. 42 (2005)).

42. Jennifer L. Skeem et al., Correctional Policy for Offenders with Mental Illness: Creating a New Paradigm for Recidivism Reduction, 35 L. \& HUM. Bl:HAV. 110, 116 (2011) (quoting Fisher, Silver, \& Wolff, supra note 34 , at 553).

43. Skeem et al., supra note 42, at 117 (generally citing inter alia JOHN MONAHAN, RisK ASSI:SSMIiNT: VIOI.INCE AND MisntAI. DisORDI:R 1 (2001) and Elizabeth Walsh et al., Violence and Schizophrenia: Examining the Evidence, 180 BRIT. J. PSYCHIATRY 490 (2002)).

44. Daniel P. Mears, Mental Health Needs and Services in the Criminal Justice System, 4 Hous. J. HliAl.TH L. \& POl'Y 255, $257-58$ (2004). On the need for enhanced mental health services after arrest, see Lamb et al., supra note 37, at 116-17.

45. James W. Ellis \& Ruth A. Luckasson, Mentaly Retarded Criminal Defendants, 53 Gr:o. WASH. L. RJiv. 414, 476 n. 351 (1985) (generally citing JAMFS W. CONROY \& VAII:RII J. Bradlity, PIinNhURST LONGITUdinAl. STUDY: A RI:PORT OF FIVI: YIiARS OF RIiSI:ARCH AND ANAIYSIS 1 (Temple University \& Human Services Research Institute 1985) ("finding that all 
Never mind that we have not even begun to do serious research into, by way of example, the specific issues that relate to the status of elderly persons with mental disabilities in the criminal justice system. ${ }^{46}$ Never mind the staggering fiscal costs of the current state of affairs. ${ }^{47}$ And never mind, most importantly of all, that " $[\mathrm{t}]$ here is no evidence for the basic criminalization premise that decreased psychiatric services explain the disproportionate risk of incarceration for individuals with mental illness," 48 that "there is little evidence that the risk of incarceration has uniquely increased for those with mental illness,"49 and that "no research exists demonstrating that mental illness is a principal or proximate cause of criminal behavior for most offenders with mental illnesses." 50

John Junginger and his colleagues state the valid and reliable research simply and precisely:

Unless it can be shown that factors unique to serious mental illness are specifically associated with behavior leading to arrest and incarceration, the criminalization hypothesis should be reconsidered in favor of more powerful risk factors for crime than are inherent in social settings occupied by persons with severe mental illness - risk factors such as unemployment, poverty, homelessness, and substance abuse. ${ }^{51}$

Pennhurst residents, regardless of level of [mental disability], could be served successfully in the community')).

46. See generally, e.g., Tina Maschi et al., Aging, Mental Health, and the Criminal Justice System: A Content Aralysis of the I iterature, 2 J. FORIiNS. SOCIAI. WORK 162 (2012).

47. See Thomas L. Hafemeister, Sharon G. Garner \& Veronica E. Bath, Forging I inks and Renewing Ties: Applying the Principles of Restorative and Procedural Justice to Better Respond to Criminal Offenders with a Mental Disorder, 60 BUFF. L. REv. 147, 221 n. 343 (2012). Contrarily, state spending for treatment of persons with serious mental illness is estimated to be one-third less now than it was in the 1950s. From Prisons to Hospitals - And Back: The Criminalization of Mental Illness, PRISON POI.'Y INITIATIVE, www.prisonpolicy.org/scans/menbrief.html (last visited Apr. 1, 2013).

48. Skeem et al., supra note 42, at 116. See also John Junginger et al., Effects of Serious Mental Illness and Substance Abuse on Criminal Offenses, 57 PSYCHIATRIC SriRvs. 879, 879 (2006) thereinafter Junginger $\Pi$ (citing John Junginger et al., Psychotic Motivations and the Paradox of Current Researcb on Serious Mental Illness and Violence, 30 SCHIZOPHRIiNIA Buid.. 21 (2004), stating that "[i]n fact, what little empirical reseatch exists on this particular interpretation of the criminalization hypothesis has produced no consensus."). See also Fisher, Silver, \& Wolff, supra note 34, at 548 ("empirical support for the 'standard' criminalization argument as a base from which to construct policy or research agendas appears weak at best.”).

49. Skeem et al., supra note 42 , at 116 (citing inter alia, FRANK \& GLiED, supra note 39, at 128 (" [] $\mid t$ would be a mistake to attribute the increase in . . . incarceration among people with SPMI directly to the experience of deinstitutionalization.")).

50. E. Lea Johnston, Theorizing Mental Health Courts, 89 WASH. U. L. REV. 519,565 (2012) (citing Nancy Wolff, Courting the Court: Courts as Agents for Treatment and Justice, in CommUNITYBasied Interventions for Criminal, Offenders with SFvere Mintal. Ili.niass 143, 155, 163 (William H. Fisher ed., 2003)).

51. Junginger I, supra note 48, at 882. See also Ginger Lerner Wren, Mental Health Courts: Serving Justice and Promoting Recovery, 19 ANNAIS HEALTH L. 577, 581 (2010): 
The "villainry" story - abetted by the pernicious use by the media and unscrupulous politicians of the vividness heuristic ${ }^{52}$ - still captures the public debate (and to some extent, the scholarly debate), but it is one that must be flatly rejected..$^{53}$

\section{Changes in Criminal Procedure}

As I indicated in the Introduction, the past thirty years have seen a cluster of changes to criminal procedure (via statute and judicial decisions, both leading to changes in practice), that, in the aggregate, make the use of an insanity defense or the raising of a mental status issue a much less attractive option to the defendant than ever before. I will look at each of these separately:

\section{A. The Shrinking of the Insanity Defense}

\section{Substantive and Procedural I imitations}

We can logically look at March 30, 1981 - the day that John Hinckley shot Ronald Reagan - as the turning point in this area of the law. In my booklength treatment of the insanity defense, I even titled a sub-chapter "Reagan as Hinckley's victim; Hinckley as Reagan's victim"54 so as to reflect this turn of events. "Post-Hinckley outrage served as a catalyst for public denunciation, which led to speedy legislative inquiry, 'reform' legislation, and ultimately, to a

The consequences of untreated mental illness and the resulting criminalization of the mentally ill can be attributed to a number of factors, including: severely underfunded community based systems of care, lack of adequate housing and the prevalence of homelessness, and the overall lack of specialized forensic services and supports for those reentering the community. Further, the increased use of illicit substances in the general population and among the mentally ill has likely made a significant contribution to an increase in all types of offenses.

On the relationship between the risk factors of substance abuse and medication noncompliance, see Borum et al., Police Encounters, supra note 41.

52. See Michael L. Perlin, "The Borderline Which Separated You From Me": The Insanity Defense, the Authoritarian Spirit, the Fear of Faking, and the Culture of Punishment, 82 IOWA L. RI:v. 1375, 1417 (1997) (defining vividness heuristic as "a cognitive-simplifying device through which a "single vivid, memorable case overwhelms mountains of abstract, colorless data upon which rational choices should be made"'). On the role of the media and of politicians in this context, see Perlin, supra note 1, at 110-11 nn. 272-76.

53. This is not to say that there are not many people with psychosocial disabilities in jails and prisons, and it in no way ignores the sobering statistics referred to earlier. See generally, e.g., Fellner, supra note 13; Canales, supra note 13. Rather, it suggests that the blame is misplaced in ways that make it less likely that we will turn to ameliorative action in an effort to remediate the problems at hand. See SI.ATI: \& JOHNSON, supra note 14, at 28-29.

54. See PI:RIIN, supra note 21, at 333-48. 
'shrinkage' of the insanity defense."'55 There is no question that the Hinckley acquittal "helped legitimize long-standing efforts at both the state and federal levels to abolish or reform the defense," 56 and that those efforts were, by and large, successful.

This shrinkage involved three components: (1) restrictions on the limits of the substantive test (in this case, the elimination of the so-called "volitional" prong in the federal Act), ${ }^{57}$ (2) alterations in the procedural aspects of the insanity plea (in this case, both the shifting of the burden of proof to the defendant, and changing the quantum of evidence necessary to sustain a plea); ${ }^{58}$ and (3) increased restrictions on insanity acquittees following their postacquittal commitment to psychiatric institutions. ${ }^{59}$

In the wake of the Reagan shooting, twenty-six different pieces of legislation were soon introduced into Congress to abolish or limit the insanity defense. ${ }^{60}$ The bill that was ultimately enacted as the Insanity Defense Reform Act of 1984 ("IDRA") had the effect of 'returning the insanity defense in federal jurisdictions to status quo ante 1843: the year of . . . [the] M'Naghten [case].' ${ }^{\prime} 1$ Fundamentally, the bill that was ultimately enacted changed the law in four material ways: 1) it shifted the burden of proof to defendants, by a quantum of clear and convincing evidence; 2) it articulated, for the first time, a substantive insanity test, adopting a more restrictive version of MNaghten, thus discarding the ALI-Model Penal Code test previously in place in all federal circuits; ${ }^{62} 3$ ) it established strict procedures for the hospitalization and release of defendants found NGRI and incompetent to stand trial; and 4) it severely limited the scope of expert testimony in insanity cases. ${ }^{63}$

Similarly, States responded in a similar manner. ${ }^{64}$ Seventy-five percent of all states made some sort of substantive change in insanity defense in the 1978-85 period. In fifteen of sixteen states that changed post-acquittal procedures, commitment terms were lengthened, court supervision was tightened, or the burden of proof was altered - by shifting the burden from state to de-

55. Michael L. Perlin, Unpacking the Myths: The Symbolism Mythology of Insanity Defense Jurisprudence, 40 CASE W. RES. L. Ri:v. 599, 613-14 (1989-90).

56. Peter Arenella, Reflections on Current Proposals to Abolish or Reform the Insanity Defense, 8 AM. J.L. \& Mi:D. 271, 272 (1982).

57. 18 U.S.C. $\$ 17($ a) (1984).

58. 2 PIRLIN, supra note 5 , at 340.

59. Perlin, supra note 55, at 614 n. 65.

60. Perlin, supra note 52, at 1382.

61. See Michael L. Perlin, "The Things We Do For I ove": Jabn Hinckley's Irial and the Future of the Insanity Defense in the Federal Courts (Book Review), 30 N.Y.L. SCH. L. REv. 857, 862 (1985); 2 PIiRI.IN, supra note 5, at 149-54 for a full discussion of the MNaghten case.

62. PliRIIN, supra note 5 , at 160-63.

63. Perlin, supra note 55 , at $638-39 \mathrm{nn} .172-77$. On how these changes were made without the benefit of any substantiating empirical evidence, see generally Carmen Cirincione \& Charles Jacobs, Identifying Insanity Acquittals: Is It Any Easier?, 23 LAW \& HUM. BEHAV. 487 (1999).

64. See generally Lisa Callahan et al., Insanity Defense Reform in the United States-Post-Hinckley, 11 Mental, \& Phys. Disabil.jty L. Risp. 54 (1987). 
fendant and/or reducing the quantum of proof from "beyond a reasonable doubt" to "preponderance of the evidence" or "clear and convincing evidence." In six of eight states that changed the substantive test, the definition was restricted [either by changing from the ALI-Model Penal Code test or M'Naghten plus irresistible impulse to $M$ 'Naghten, or by restricting insanity defense testimony to mens rea evidence] ${ }^{65}$ In twelve jurisdictions, a Guilty But Mentally Ill ("GBMI") verdict ${ }^{66}$ was added. ${ }^{67}$

In four states, the defense has been abolished. ${ }^{68}$ Interestingly, where the insanity defense has been abolished, there is often a statistically significant increase in the number of defendants found permanently incompetent to stand trial. ${ }^{69}$

In short, the insanity defense - never an attractive option for a criminal defendant ${ }^{70}-$ has become far less attractive in the past thirty years. Inevitably,

65. In Clark v. Arizona, 548 U.S. 735,747 (2006), the Supreme Court rejected a constitutional challenge to an Arizona law, ruling that it was not a due process violation for a state to "narrow $\|$ its insanity test or [exclude] evidence of mental illness and incapacity due to mental illness to rebut evidence of the requisite criminal intent." Commentary on Clark has been almost wholly negative. See Michali. L. Pliki.in \& Hiiathis E. Cucolo, Miental. Disabil.ity LAW: CIVIL, AND CRIMINAI.(2012 CUM. SUPP.), at 81-82 nn. 277.94 (citing sources).

66. See 2 PIERIIN, supra note 5, at 169-79. I believe that that defense is "superfluous" and "dangerous," (see Joseph Rodriguez et al., The Insanity Defense Under Siege: I egislative Assaults and legal Rejoinders, 14 RUTGirRs L.J. 397, 411 (1983)), and "deceptive and hollow[.]" Pı:RI.IN, supra note 21 , at 95 . Of course, defendants who "successfully" plead GBMI go to prison and usually have no right to mental health services or treatment beyond that of the "ordinary" prisoner. See Bradley D. McGraw et al., The "Guilty But Mentally Ill" Plea and Verdict: Current State of the Knowledge, 30 Vilı.. L. REv. 117, 187 (1985).

67. 2 PliRLin, supra note 5, at 347 n. 125 (discussing the research in Callahan et al., supra note 64). Perlin, supra note 52, at 1376-77. See also George L. Blau \& Richard A. Pasewark, Statutory Changes and the Insanity Defense: Seeking the Perfect Insane Person, 18 LAW \& PSYCHOI. RIiV. 69 (1994).

68. Montana, Idaho, Utah, and Kansas have abolished the insanity defense. See Henry F. Fradella; From Insanity to Beyond Diminished Capacity: Mental Mllness and Criminal Excuse in the PostClark Era, 18 U. Fl.A. J.L. \& PuB. Pol'Y 7, $34-35$ (2007). See also Cynthia G. Hawkins-León, "I Aterature as I aw": The History of the Insanity Plea or a Fictional Application Within the I aw of I iterature Canon, 72 Timp. L. Riv. 381, 405 (1999).

69. See Rita Buitendorp, A Statutory I esson from "Big Sky Country" on Abolishing the Insanity Defense, 30 VAL. U. L. Riv. 965, 993-96 (1996) (discussing research reported in Henry J. Steadman et al., Maintenance of an Insanity Defense Under Montana's "Abolition" of the Insanity Defense, 146 AM. J. Psychiatry 357, 359-60 (1989)).

70. On how jurors' pre-existing " "knowledge structures' ... strongly influence their case judgments" in insanity trials, see Jennifer L. Skeem \& Stephen L. Golding, Describing Jurors' Personal Conceptions of Insanity and 'T 'beir Relationship to Case Judgments, 7 PSYCHOL. PUB. POL'Y \& L. 561,561 (2001). On how their attitudes about the defense in se "powerfully influence" their information processing in their decision making, see Jennifer Eno Louden \& Jennifer L. Skeem, Constructing Insanity: Jurors' Prototypes, Attitudes, and I egal Derision-Making, 25 Bi:HAv. SCI. \& L. 449, 462 (2007). On juror inflexibility in this regard, even after being provided with correct information, see Jennifer Skeem, Jennifer Eno Louden, \& Jennee Evans, Venire Persons' Attitudes Toward the Insanity Defense: Developing, Refining, and Validating a Scale, 28 LAW \& HUM. BiHAV. 623, 625 (2004). 
this has increased the number of persons with serious mental illness in state prisons.

\section{The Implications of Raising the Defense}

One of the prevailing insanity defense myths is that insanity acquittees "spend much less time in custody than do defendants convicted of the same offenses." 71 Contrary to this myth, NGRI acquittees actually spend almost double the amount of time that defendants convicted of similar charges spend in prison settings and often face a lifetime of post-release judicial oversight. ${ }^{72}$ Most importantly for the perspectives of this presentation, the less serious the offense, the longer the gap is between the amount of time that an insanity acquittee serves ${ }^{73}$ and the amount of time that a convicted defendant serves. A California study, by way of example, has revealed that those found NGRI of non-violent crimes were confined for periods over nine times as long. ${ }^{74}$ Thus, it makes progressively less sense for a defendant to raise the insanity defense. ${ }^{75}$

But there is more. Just raising the defense is a high-risk maneuver. Defendants who raise the insanity defense and are unsuccessful serve significantly longer sentences than those who did not assert the defense. ${ }^{76}$ Also, the Supreme Court decision in Shannon $v$. United States, which held that, as a matter of federal criminal procedure, the defendant had no right to have the jury

71. Plerian, supra note 21, at 110. On how the valid and reliable research on the insanity defense contradicts most of the "commonly-held beliefs" about the defense's usage, see Randy Borum \& Solomon M. Fulero, Empirical Research on the Insanity Defense and Attempted Reforms: Evidence Toward Informed Policy, 23 LAW \& HUM. BLHAv. 375, 378 (1999).

72. Perlin, supra note 55, at 651 (citing empirical results reported in Rodriguez et al., supra note 66, at 403-04, and Mark Pogrebin et al., Not Guilty By Reason of Insanity: A Research Note, 8 INT'L. J.L. \& PSYCHIATRY 237, 240 (1986)).

73. I use the word "serve" consciously, as invariably, this cohort of defendants is institutionalized in a maximum-security, prison-like setting. See Michacl L. Perlin, $A$ I aw of Healing, 68 U. CiN. L. Riv. 407, 428 (2000).

74. Perlin, supra note 52, at 1405 (discussing research reported in HisnRY STEADMAN ET al., Reforming the Insanity Defense: An Analysis of Pre- and Post-Hinckiley REFORMS 94 (1993)). A National Mental Health Association report found that as many as $86 \%$ of insanity pleas occur in nonviolent felonies and misdemeanors. See Elizabeth NevinsSaunders, Not Guilly As Charged: The Myth of Mens Rea for Defendants with Mental Retardation, 45 U.C. Davis L. Riv. 1419, 1454 n. 172 (2012) (discussing NAT'L. Mrintal. Hi:AlTh Ass'N, MYTHS \& REALITIES: A REPORT OF THE NATIONAL COMMISSION ON THE INSANITY DIFHENSI: 20-21 (1983)).

75. See, e.g., Sherin S. Vitro, Promoting Therapeutic Objectives Through I.B 518: A Same Amendment to Nebraska I aw Governing the Disposition of Insanity Acquittees, 72 NEB. L. Rkv. 837, 844 (1993) (" $[\mathrm{A}] \mathrm{n}$ individual in need of treatment may fail to assert the insanity defense because a criminal sentence would be of definite and frequently shorter duration.").

76. PERLin, supra note 21, at 109; Rodriguez et al., supra note 66, at 401-02, 402 n. 32. See Jeraldine Braff, Thomas Arvinites, \& Henry J. Steadman, Detention Patterns of Successful and Unsuccessful Insanity Defendants, 21 CRIMINOL.OGY 439, 445 (1983) (defendants who raised the insanity defense and were unsuccessful were incarcerated for $22 \%$ longer as compared to those who did not raise the defense). 
informed about the possible consequences of a not guilty by reason of insanity verdict, ${ }^{77}$ will likely make it even less likely that the insanity defense will be employed. Elsewhere, I have characterized this decision as "bizarre."78

Not unimportantly, this state of affairs will likely increase the amount of pretextuality in decision making in this area of the law. ${ }^{79}$ In her opinion for the Court in Penry v. Lynaugh, ${ }^{80}$ Justice O'Connor argued:

The common law prohibition against punishing "idiots" for their crimes suggests that it may indeed be "cruel and unusual" punishment to execute persons who are profoundly or severely retarded and wholly lacking the capacity to appreciate the wrongfulness of their actions. Because of the protections afforded by the insanity defense today, such a person is not likely to be convicted or face the prospect of punishment. ${ }^{81}$

I wrote nearly ten years ago that this statement "ignores the postHinckley political reality that the insanity defense has been severely truncated in many jurisdictions and has been 'abolished' in others," 82 and certainly nothing has happened in the intervening decade to lead me to change my mind on this point. As with the substantive reduction of the insanity defense and its procedural tightening discussed above, these factors again, make the insanity defense an even less attractive option.

\section{The Length of Post-acquittal Commitments}

In 1983, the Supreme Court ruled, in Jones $v$. United States, ${ }^{83}$ that it was not unconstitutional to retain insanity acquittees for longer periods of time than the maximum sentence for the underlying crime, ${ }^{84}$ finding that there is no correlation between severity of crime committed and time necessary for "recovery." 85 The defendant in Jones had been arrested for attempted petty

77. 512 U.S 573 (1994).

78. 2 PERLIN, supra note 5, at 197, 199 (characterizing the decision as either "atypically naive, meretricious, or simply deceitful').

79. Prextextuality defines the ways in which courts accept (either implicitly or explicitly) testimonial dishonesty and engage similarly in dishonest (and frequently meretricious) decisionmaking. See generally Michafil L. Pisilin, The Hiddin Prejudicli: Mental Disability on Trial 1 (2000); Michael L. Perlin, "Half-Wracked Prejudice I eaped Forth": Sanism, Pretextuality, and Why and How Mental Disability l aw Developed as It Did, 10 J. CONTIMP. LI:GNL. Issues 3 (1999). See also Perlin, supra note 21, at 428-29 (Shannon "will only increase the amount of pretextuality in decisionmaking in this arca of the law.").

80. 492 U.S. 302 (1989) (rejecting categorical ban on execution of persons with mental retardation), overruled by Atkins v. Virginia, 536 U.S. 304 (2002). See generally Perlin, Death Disappears, supra note 22.

81. Penry, 492 U.S. at 333 .

82. Perlin, Death Disappears, supra note 22, at 324-25.

83. 463 U.S. 370 (1983).

84. Id. at 359 .

85. Id. at 369 . 
larceny (shoplifting); yet, the Court saw no reason to treat a misdemeanor case any different from a case involving a murder, rape, or armed robbery. In its decision, the Court quoted an earlier decision of the District of Columbia Circuit that had been written by Chief Justice Burger: "[T]o describe the theft of watches and jewelry as 'non-dangerous' is to confuse danger with violence. Larceny is usually less violent than murder or assault, but in terms of public policy the purpose of the statute is the same as to both." 86

Jones was a political decision that permitted indeterminate commitment and reflected the Supreme Court's "unwillingness to contradict public sentiment (soon after the Hinckley acquittal) in such a controversial area." 87 "It further provided the Court with a vehicle to impose its dissatisfaction with the insanity defense on defendants who succeeded in the use of a plea by making it even less likely that the plea would be used in the future," 88 "illuminat[ing] the Court's antipathy toward insanity pleaders." 89

\section{B. The Perils of Raising the Incompetency Status}

Unlike the insanity defense, which can be raised only by the defendant, defense counsel, the prosecutor or the judge can raise the question of incompetency, if there is a "bona fide doubt" that the defendant is, in fact, competent to stand trial..$^{90}$ Although, generally, this is done on application of defense

86. Id. at 365 n. 14.

87. Michael L. Perlin, "For the Misdemeanor Outlaw?: The Impact of the ADA on the Institutionalization of Criminal Defendants with Mental Disabilities, 52 Al_ABAMA L. Riv. 193, 211-12 (2000) (quoting, in part, Louise Dovre, Jones v. United States: Automatic Commitment of Individuals Found Not Guilty by Reason of Insanity, 68 MINN. L. RivV. 822, 840 (1984)). On how decisions such as Jones "enhance the 'clutchability' of successful insanity defendants," see John La Fond \& Mary Durham, Cognitive Dissonance: Have Insanity Defense and Civil Commitment Reforms Made a Difference?, 39 VILL. L. RI:V. 71, 104 (1994). On the concept of "clutchability" in general in criminal law, see e.g., Joel Feinberg, Crime, Clutchability, and Individuated Treatment, in DOING \& DiserviNG: ESSAYS IN THE THEORY OF RISSPONSIBILITY 252 (1970). On the concept in the context of mental health courts, see Chelsea Davis, Therapeutic Jurisprudence, Drug Courts, and Mental Health Courts: With the Best of Intentions, 3 J. MISNTAL. HiAl.TH L. \& POL'Y (Forthcoming 2013).

88. Perlin, supra note 87, at 212; PERL.IN, supra note 21, at 200-01. See also, e.g., Janet Polstein, Throwing Away the Key: Due Process Rights of Insanity Acquittees in Jones v. United States, 34 AM. U. L. REv. 479, 521 (1985). At least one study found that the post-Hinckley statutory changes to the insanity defense in multiple states resulted in fewer defendants entering insanity

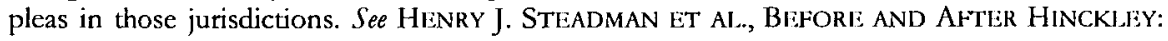
EVAluATING InSANITY DEFENSE RlForm 38 (1993) (as discussed in Fradella, supra note 68, at 37-38).

89. Perlin, supra note 87 , at 194 . For changes in the reduction of the use of the insanity defense after Hinckley and Jones, see generally, Lisa Callahan, Factors Associated with the Conditional Release of Persons Acquitted by Reason of Insanity: A Decision Tree Approach, 22 LAw \& Hum. BuHAv. 147 (1998); Lisa Callahan, Connie Meyer \& Henry Steadman, The Volume and Characteristics of Insanity Defense Pleas: An Eight-State Study, 19 J. AM. ACAD. PSYCHIATRY \& L. 331 (1991).

90. See, e.g., 4 PliRI.IN, supra note 5, at 13-14; Pate v. Robinson, 383 U.S. 375, 378 (1966); State v. Johnson, 218 P.3d 46, 53 (Kan. 2009); Lynda E. Frost \& Adrienne E. Volenik, Tbe 
counsel or by the court, there are isolated jurisdictions in which the district attorney appears to do this regularly. ${ }^{91}$ What has become clear now is that the mere raising of the status can place the defendant at great risk.

First, in spite of the Supreme Court's decision forty years ago in Jackson $v$. Indian $a^{92}$ that a person charged by a State with a criminal offense who is committed solely on account of his incapacity to proceed to trial cannot be held "more than the reasonable period of time necessary to determine whether there is a substantial probability that he will attain that capacity in the foreseeable future," 93 astoundingly, this decision continues to be ignored by half the states. ${ }^{94}$ What this means is that individuals who should "fit" under the language of Jackson are often kept in maximum-security facilities for far longer than the three and a half year "cut off" period adopted by the Jackson court.95 At least one state Supreme Court has specifically sanctioned procedures that ignore the Jackson holding. ${ }^{96}$

Etbical Perils of Representing the Juvenile Defendant Who May Be Incompetent, 14 WASH. U. J.L. \& POI.'Y 327,331 (2004).

91. See Michael L. Perlin, "Too Stubborn To Ever Be Governed By Enforced Insanity": Some Therapeutic Jurisprudence Dilemmas in the Representation of Criminal Defendants in Incompetency and Insanity Cases, 33 INT'I.J. L. \& PSYCHIATRY 475, 480 n. 63 (2010):

When I presented parts of this paper to the American-Psychology Law Society conference two years ago, I noted that, in my experience, this was done almost exclusively by defense counsel, and then said jokingly, "except on the TV show Law and Order, where the District Attorney character seems to raise it remarkably frequently." At this point, several hands went up, and members of the audience noted their disagreement, pointing out that in their jurisdiction, incompetency was frequently raised by the D.A.I asked where they were from, and all were from Hamilton County, Ohio (Cincinnati). I have yet to hear of this practice being prevalent in any other jurisdiction.

92. 406 U.S. 715 (1972).

93. Id. at 738 .

94. See Bruce Winick, Restructuring Competency to Stand Trial, 32 UCLA L. RI:V. 921, 941 (1985). See also Ellen C. Wertlieb, Individuals With Disabilities in the Criminal Justice System: A Review of the I iterature, 18 CRIM. JUST. \& BFHAV. 332, 336 (1991). Winick's research has been updated in Grant Morris \& J. Reid Meloy, Out of Mind? Out of Sight: The Uncivil Commitment of Permanently Incompetent Criminal Defendants, 27 U.C. DAvis L. Riv. 1, 8 (1993) (A decade after Winick published his article, Jackson remained "ignored [and] circumvented.") See Perlin, supra note 87, at 204 (" $[\mathrm{M}$ |ore than half the states allow for the indefinite commitment of incompetent-to-standtrial defendants, in spite of Jackson's specific language outlawing this practice."). See also generally Andrew R. Kaufman, Bruce B. Way, \& Enrico Suardi, Forty Years After Jackson ע. Indiana: States' Compliance with "Reasonable Period of Time" Ruling, 40 J. AM. ACAD. PSYCHIATRY \& L. 261 (2012) (showing most states out of compliance with Jackson). I discuss the significance of the earlier findings in Michael L. Perlin, Fatal Assumption: $A$ Critical Evaluation of the Role of Counsel in Mental Disability Cases, 16 LAw \& HuM. Bi:HAv. 39, 47-48 (1992).

95. See Jackson, 406 U.S. at 738-39 ("We note . . that petitioner Jackson has now been confined for three and one-half years on a record that sufficiently establishes the lack of a substantial probability that he will ever be able to participate fully in a trial.").

96. See State v. Werner, 796 P.2d 610, 613 (N.M. Ct. App. 1990) (showing it was not error to treat dangerous patients committed pursuant to Jackson differently from civil patients). 
The mere raising of the incompetency status is often a perilous decision. There are multiple reasons why an effective and competent defense lawyer might not even raise the question of incompetency, among them the lack of availability of bail, the conditions of institutionalization at the referral hospital, and the possible iatrogenic or ameliorative impact of psychiatric institutionalization on the defendant. .7 Josephine Ross has suggested that an "ethic of care" might call for disregarding incompetency concerns, ${ }^{98}$ and Christopher Slobogin and Amy Mashburn underscore that the raise-or-not-raise decision is necessarily a "nuanced" one." In a particularly thoughtful piece, Keri Gould has argued that the Sixth Amendment right to effective counsel may ethically support the decision to ignore the competency question entirely. ${ }^{100}$ This issue is of special importance in the case of defendants charged with petty offenses who face little or no jail time if convicted, but who may be institutionalized for years in maximum security facilities once the status issue is raised. ${ }^{101}$

This all raises the spectre of what is called the "incredible dilemma:" What can or should be done when multiple civil, constitutional, or statutory rights and policies clash? ${ }^{102}$ Certainly, an outcome of this dilemma is likely to cause a reduction of the number of cases in which the incompetency status is raised, thus, increasing the number of defendants with mental disabilities in jail and prison facilities.

Second, involuntary medication is often the intervention of choice when restoration of competency to stand trial is sought. The Supreme Court's decision in Sell $\nu$. United States ${ }^{103}$ - holding that although a defendant has a qualified right to refuse to take antipsychotic drugs prescribed solely to render him competent to stand trial, medication over objection is permissible where the court finds that treatment is medically appropriate, is substantially unlikely to have side effects that may undermine the fairness of the trial, and, taking ac-

97. See 2 PliRi.lN, supra note 5, at 61. See generally Paul A. Chernoff \& William G. Schaffer, Defending the Mentally Ill: Ethical Quicksand, 10 AM. CRIM. L. RIiV. 505 (1972).

98. Josephine Ross, Autonomy Versus a Client's Best Interests: The Defense I anyer's Dilemma When Mentally Ill Clients Seek to Control Their Defense, 35 AM. CRIM. L. REv. 1343, 1372-81 (1998).

99. Christopher Slobogin \& Amy Mashburn, The Criminal Defense I anyer's Fiduciary Duty to Clients with Mental Disability, 68 FORDHAM L. Rıv. 1581, 1622 (2000).

100. See Keri A. Gould, A Therapeutic Jurisprudence Analysis of Competency Evaluation Requests: The Defense Attomey's Dilemma, 18 InT'L J.L. \& PsychIATRY 83, 91-95 (1995). Gregory Brown, The Case of John Salvi: Ethical Binds When Representing the Incompetent Defendant, 4 SUFFOIK J. TRIAL \& APP. ADVOC. 49, 61 (1999) ("Whatever the motivation for refusing to raise incompetence, such a refusal on the part of the defendant can put defense counsel in an ethical bind between the duty to advocate zealously for their client and the duty to raise the issue of competency to stand trial.").

101. See supra note 94 and accompanying text.

102. See Michael L. Perlin, Hospitalized Patients and the Right to Sexual Interaction: Beyond the L ast Frontier? 20 N.Y.U. Rev. L. \& SOC. CHANGE 517, 540 (1993-94) (discussing Peter Westen, Incredible Dilemmas: Conditioning One Constitutional Right on the Forfeiture of Another, 66 IOwA L. REV. 741, $742(1981)$ ).

103. 539 U.S. $166(2003)$. 
count of less intrusive alternatives, is necessary significantly to further "important governmental trial-related interests"104 - makes it clear that many defendants will be so medicated as part of the restoration process. ${ }^{105} \mathrm{Few}-$ if any - areas of mental disability law have been as contentious over the years as the right to refuse treatment in civil cases, ${ }^{106}$ an area where "civil treatmentrefusers" are likely to have more rights than do forensic patients. ${ }^{107}$ Certainly, raising the incompetency status, knowing that it brings with it the potential risk of such involuntary medication becomes a potentially perilous decision for defense counsel. In short, defendants seeking to avoid the perils of involuntary medication might well be better off ignoring the question of their competency to stand trial.

\section{Conclusion}

Every change to the insanity defense in the past thirty years, and every aspect of incompetency-to-stand-trial practice has made it less likely that these statuses/defenses will be employed in cases of defendants with mental illness - especially major mental illness - and charged with crime - especially minor crimes. Astoundingly, to my mind, this factor has never been raised seriously in the "criminalization" debate.

I turn now to the use of therapeutic jurisprudence as a potential tool of remediation.

\section{THERAPEUTIC JURISPRUDENCE ${ }^{108}$}

One of the most important legal theoretical developments of the past two decades has been the creation and dynamic growth of therapeutic jurisprudence. ${ }^{109}$ Initially employed in cases involving individuals with mental dis-

104. Id. at 180-81. See generally Michael L. Perlin, “And My Best Friend, My Doctor / Won't Even Say What It Is I've Got": The Role and Significance of Counsel in Right to Refuse Treatment Cases, 42 SAN Diligo L. Riv. 735, 736 (2005).

105. See PIiRIIN \& CuCOl.O, supra note 65, at 18-27, 24-27 n. $369.41-369.58$ (discussing post-Selllitigation).

106. See, e.g., Perlin, supra note 104 , at 736 (for over 30 years, the right to refuse treatment "has been the most contentious issue in the 'turf' battle between what is incorrectly characterized as 'law and psychiatry"').

107. See generally 2 PI:RIIN, supra note 5, at 189-330.

108. This section is largely adapted from Michael L. Perlin, "Siriking for the Guardians and Protectors of the Mind": The Convention on the Rights of Persons with Mental Disabilities and the Future of Guardianship I aw, 117 Plinn ST. L. Rı:v. 1159 (2013); Michael L. Perlin, "John Brown Went Off to War": Considering Veterans' Courts as Problem-Solving Courts, 3 Nova L.. Ruiv. (forthcoming 2013) Thereinafter Perlin, Veterans' Courts]; and Michael L. Perlin, "There Are No Trials Inside the Gates of Eden": Mental Health Courts, the Convention on the Rights of Persons with Disabilities, Dignity, and the Promise of Therapeutic Jurisprudence, in COlsRCIVI: CARl: LAW AND POLICY (Bernadette McSherry \& Ian Freckelton eds. forthcoming 2013) (hereinafter Perlin, Gates of Eden].

109. See generally, e.g., David B. Wixiler, ThIiRAPIiUTIC JURISPRUDINCl: THI: LAW AS A Thisapliutic AGHNT 1 (1990); DAVID B. WI:XIII:R \& BruCli J. WINICK, LAW IN A 
abilities, but subsequently expanded far beyond that narrow area, therapeutic jurisprudence presents a new model for assessing the impact of case law and legislation, recognizing that, as a therapeutic agent, the law can have therapeutic or anti-therapeutic consequences. ${ }^{110}$ The ultimate aim of therapeutic jurisprudence is to determine whether legal rules, procedures, and lawyer roles can or should be reshaped to enhance their therapeutic potential while not subordinating due process principles. ${ }^{111}$ There is an inherent tension in this inquiry, but David Wexler clearly identifies how it must be resolved: "the law's use of "mental health information to improve therapeutic functioning [cannot] impinge upon justice concerns." 112 As $I$ have written elsewhere, "[a]n inquiry into therapeutic outcomes does not mean that therapeutic concerns 'trump' civil rights and civil liberties."113

Therapeutic jurisprudence "asks us to look at law as it actually impacts people's lives"114 and focuses on the law's influence on emotional life and

Therapeutic Key: Recent Devilopments in Therapeutic Jurisprudence 1 (1996); Bruce J. Winick, Civil. Commitmint: A Thlirapeutic Jurisprudince Model 1 (2005); David B. Wexler, Two Decades of 'Therapeutic Jurisprudence, 24 TOURO L. Rev. 17 (2008); 2 PERLIN, supra note 5, at 534-41. Wexler first used the term in a paper he presented to the National Institute of Mental Health in 1987. See David B. Wexler, Putting Mental Health into Mental Health L aw: Therapeutic Jurisprudence, 16 L. \& HUM. BEHAV. 27, 27, 32-33 (1992).

110. See Michael L. Perlin, "His Brain Has Been Mismanaged with Great Skill": How Will Jurors Respond to Neuroimaging Testimony in Insanity Defense Cases?, 42 AKRON L. Rivv. 885, 912 (2009); see Kate Diesfeld \& Ian Freckelton, Mental Health l and and Therapeutic Jurisprudence, in DisPUTES AND Dilimmas In Hizalth Law 91 (Ian Freckelton \& Kate Peterson eds., 2006) (for a transnational perspective).

111. See generally Michael L. Perlin, "You Have Discussed Lepers and Crooks": Sanism in Clinical Teacbing, 9 CuINICAL L. Rev. 683 (2003); Perlin, supra note 104; Michael L. Perlin, "Everybody Is Making Love/Or Else Expecting Rain": Considering the Sexual Autonomy Rights of Persons Institutionalized Because of Mental Disability in Fonensic Hospitals and in Asia, 83 U. WASH. L. Riv. 481 (2008) [hereinafter Perlin, Expecting Rain].

On how therapeutic jurisprudence "might be a redemptive tool in efforts to combat sanism, as a means of 'strip[ping] bare the law's sanist façade,"' see Michael L. Perlin, "Baby, I ook Inside Your Mirror": The Legal Profession's Willful and Sanist Blindness to Lanyers with Mental Disabilities, 69 U. PITT. L. Rivv. 589, 591 (2008) (quoting, in part, PriRL.IN, supra note 78, at 301). See also Bernard P. Perlmutter, George's Story: Voice and Transformation through the Teacbing and Prattice of Therapeutic Jurisprudence in a L aw School Cbild Advocacy Clinic, 17 ST. THOMAS L. REv. 561, 599 n. 111 (2005). Ian Freckelton, Therapeutic Jurisprudence Misunderstood and Misrepresented: The Price and Risks of Influence, $30 \mathrm{~T}$. J EFFliRSON L. Rkv. 575, 585-86 (2008).

112. David B. Wexler, Therapeutic Jurisprudence and Changing Concepts of I egal Scholarship, 11 BenAv. SCI. \& L. 17, 21 (1993). See also, e.g., David Wexler, Applying the Iaw Therapeutically, 5 APPL. \& PREVIENT. PSYCHOL. 179 (1996).

113. Perlin, supra note 21, at 412; Michael L. Perlin, "Where the Winds Hit Heavy on the Borderline": Mental Disability L aw, Theory and Practice, Us and Them, 31 LoYOl.A L.A. L. Riv. 775, 782 (1998).

114. Bruce J. Winick, Foreword: Therapeutic Jurisprudence Perspectives on Dealing With Victims of Crime, 33 Nova L. Riv. 535, 535 (2009). 
psychological well-being. 115 It suggests that "law should value psychological health, should strive to avoid imposing anti-therapeutic consequences whenever possible, and when consistent with other values served by law should attempt to bring about healing and wellness". 116

In recent years, scholars have considered a vast range of topics through a therapeutic jurisprudence lens, including, but not limited to, all aspects of mental disability law, domestic relations law, criminal law and procedure, employment law, gay rights law, and tort law. ${ }^{117}$ As Ian Freckelton has noted, "it is a tool for gaining a new and distinctive perspective utilizing sociopsychological insights into the law and its applications." 118 It is also part of a growing comprehensive movement in the law towards establishing more humane and psychologically optimal ways of handling legal issues collaboratively, creatively, and respectfully. ${ }^{119}$ In its aim to use the law to empower individuals, enhance rights, and promote well-being, therapeutic jurisprudence has been described as "a sea-change in ethical thinking about the role of law . . . a movement towards a more distinctly relational approach to the practice of law ... which emphasises psychological wellness over adversarial triumphalism." 120 That is, therapeutic jurisprudence supports an ethic of care. ${ }^{121}$

115. David B. Wexler, Practicing Therapeutic Jurisprudence: Psychological Soft Spots and Strategies, in Danili. P. Stollj; David B. Wixiler \& Brucle J. Winick, Practicing Therapleutc Jurisprudincli: LAw as a Histping Profission 45 (Stolle et al. eds., 2006).

116. Bruce Winick, A Therapeutic Jurisprudence Model for Civil Commitment, in INvOLUNTARY Detention and Thlirapliutic Jurisprudincli: Intisnational. Pliksplictive on Civil. Commitmint 23, 26 (Kate Diesfeld \& Ian Freckelton, eds., 2003).

117. Michael L. Perlin, "Things Have Changed": I ooking at Non-institutional Mental Disability law Through the Sanism Filter, 46 N.Y.L. SCH. L. RIvV. 535, 537 (2002-03).

118. Diesfeld \& Freckelton, supra note 110, at 582.

119. Susan Daicoff, The Role of Therapeutic Jurisprudence Witbin Tbe Comprebensive Ian Movement, in Danili. P. Stol.li: David B. Wiexi.je, \& Brucli J. Winick, Practicing Thisapiatc Jurisprudinch: Law as a Hriping Profission 365 (Stolle et al. eds., 2006).

120. Warren Brookbanks, Therapeutic Jurisprudence: Conceining an Ethical Framework, 8 J.L. \& MkD. 328, 329-30 (2001). See also Bruce J. Winick, Overcoming Psychological Barriers to Settlement:

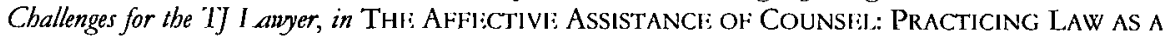
Hisaling Profission 342 (Marjorie A. Silver ed., 2007); Bruce J. Winick \& David B. Wexler, The Use of 'Therapeutic Jurisprudence in I aw School Clinical Education: Transforming the Criminal I aw Clinic, 13 Cl.INICAI L. Risv. 605, 605-06 (2006). The use of the phrase dates to Carol Gilligan's book, IN A DIFFIRISNT VOICl: (1982).

121. See, e.g., Bruce J. Winick \& David B. Wexler, The Use of Therapeutic Jurisprudence in Law School Clinical Education: Transforming the Criminal Iaw Clinic, 13 Ci.INICAI. L. REv. 605, 605-07 (2006); David B. Wexler, Not Such a Party Pooper. An Attempt to Accommodate (Many of) Professor Quinn's Concems about 'Therapeutic Jurisprudence Criminal Defense I auyering, 48 B.C. L. Ri:V. 597, 599 (2007); Brookbanks, supra note 120; Gregory Baker, Do You Hear the Knocking at the Door? A "I herapeutic" Approach to Enriching Clinical I egal Education Comes Calling, 28 WHITTlliR L. RIiv. 379, 385 (2006). 
One of the central principles of therapeutic jurisprudence is a commitment to dignity. ${ }^{122}$ Professor Amy Ronner describes the "three Vs": voice, validation and voluntariness, ${ }^{123}$ arguing:

What "the three Vs" commend is pretty basic: litigants must have a sense of voice or a chance to tell their story to a decision maker. If that litigant feels that the tribunal has genuinely listened to, heard, and taken seriously the litigant's story, the litigant feels a sense of validation. When litigants emerge from a legal proceeding with a sense of voice and validation, they are more at peace with the outcome. Voice and validation create a sense of voluntary participation, one in which the litigant experiences the proceeding as less coercive. Specifically, the feeling on the part of litigants that they voluntarily partook in the very process that engendered the end result or the very judicial pronunciation that affects their own lives can initiate healing and bring about improved behavior in the future. In general, human beings prosper when they feel that they are making, or at least participating in, their own decisions. ${ }^{124}$

The question to be addressed here is this: in light of what I have discussed in the prior parts of this paper (the data as to the real relationship between mental illness and criminalization, and the impact of recent insanity defense and incompetency developments on the "pathways" of persons with serious mental disabilities charged with crime), to what extent does therapeutic jurisprudence offer us remediating suggestions and/or solutions?

\section{CONTEXTUAlizing CRiminal JUSTICE AND MENTAL DiSABILITY}

What should be clear from the earlier sections of this article is that the common wisdom is mostly wrong about the relationship between criminalization and mental disability. It is wrong in its characterization of how the current state of affairs came about, it is wrong in the causal connections it makes, and it is wrong in its failure to inquire into the ways that changes in criminal law and procedure must be carefully considered in any investigation of this issue. This is not to say that there is no connection between criminality and

122. See Bruci: J. Winick, Civil. COMmitmint: A ThIsRapisutic Jurisprudence Modil. 161 (2005).

123. Amy D. Ronner, The Leamed-Helpless Lanyer. Clinical Legal Education and Therapeutic Jurispurdence as Antidotes to Bartleby Syndrome, 24 Touro L. RFV. 601, 627 (2008). On the importance of "voice," see also Diesfeld \& Freckelton, supra note 110, at 588.

124. Amy D. Ronner, Songs of Validation, Voice, and Voluntary Participation: Therapeutic Jurisprudence, Miranda and Juveniles, 71 U. CiN. L. REv. 89, 94-95 (2002). See generally AMY D. RONNER, LAW, LITERATURE AND THIRAPEUTIC JURISPRUDIENCE 1 (2010). 
mental disability at all, ${ }^{125}$ but that the connection is a modest one and one that applies only to a small subgroup of the relevant population. ${ }^{126}$

Researchers such as Jennifer Skeem and her associates have done a herculean job of pointing this out, but sadly much of their work - all validated, all reliable - has fallen on deaf ears, perhaps because it is, in so many ways, dissonant with our warped "ordinary common sense [OCS]."127 Writing recently about the impact of this false OCS on our insanity defense jurisprudence, I said this:

Reliance on OCS is one of the keys to an understanding of why and how, by way of example, insanity defense jurisprudence has developed. Not only is it pre-reflexive and selfevident, it is also susceptible to precisely the type of idiosyncratic, reactive decision making that has traditionally typified insanity defense legislation and litigation. ${ }^{128}$

125. See Skeem, supra note 42, at 117-18 (emphasis added).

126. See id. at 118 (discussing the research reported on in Jillian Peterson et al, Analyzing Offense Patterns as a Function of Mental Illness to Test the Criminalization Hypothesis, 61 PSYCHIATRIC Sirrv. 1217, 1220 (2010) (only 7\% of persons with mental illness "clearly fit the criminalization hypothesis")).

127. See Michail. L. Pliri. an, A Priscription for Dignity: Rithinking Criminai. JUSTICI: AND MIiNTAI. DiSABILITY LAW (forthcoming 2013) (manuscript at 31) (on file with author) (citations omitted):

"Ordinary common sense" (OCS) is a "powerful unconscious animator of legal decision making." It is a psychological construct that reflects the level of the disparity between perception and reality that regularly pervades the judiciary in deciding cases involving individuals with mental disabilities. OCS is self-referential and non-reflective: "I see it that way, therefore everyone sees it that way; I see it that way, therefore that's the way it is." It is supported by out reliance on a series of heuristics-cognitive-simplifying devices that distort our abilities to consider information rationally.

128. Id. at 32. On the role of false OCS in the perpetuation of false beliefs in police and criminal psychology, see Michael G. Aamodt, Reducing Misconceptions and False Beliefs in Police and Criminal Psychology, 35 CRIM. JUST. \& BliHAV. 1231 (2008) (discussing the role of false OCS in the perpetuation of false beliefs in police and criminal psychology). See also Lurigio, supra note 36, at 11; David Flagel \& Paul Gendreau, Sense, Common Sense, and Nonsense, 35 Crim. Just. \& Birhav. 1354 (2008) (discussing the relationship between such OCS and attitudes towards law enforcement in general); Louden \& Skeem, supra note 70, at 465-66 (discussing the role of OCS with regard to juror's false belief about the insanity defense); Jennifer L. Mnookin, The Courts, the NAS, and the Future of Forensic Science, 75 BROOK. L. RIV. 1209, 1209 (2010) (demonstrating this phenomenon through relating a story about a conversation she had with her seatmate on a recent airline flight):

On a recent flight, the person next to me on the crowded airplane began to chat with me. When I told her about what I researched and studied, she looked at me with a big grin. "I LOVE forensic science," she said. "I watch CSI whenever I can. They can do such amazing things. It's all so high tech-and incredibly accurate! It's almost like magic, isn't it?" She leaned in a bit closer and looked at me intently. "Tell me, is it like that in real life?"

I looked at her for a moment before answering. I felt a bit like the older child on the playground about to reveal to her younger friend that Santa Clause doesn't really exist. I shook my head. "No, I wouldn't say that CSI's depiction is entirely realistic. In the re- 
Certainly, this is a major culprit in the area of law and social policy under discussion here.

Consider, then, the potential application of therapeutic jurisprudence to this state of affairs. In doing this, it is necessary to consider all of this in the specific context of mental health courts. ${ }^{129}$ Briefly, mental health courts - one form of "problem-solving courts" 130 - follow the legal theory of therapeutic jurisprudence, in an attempt "to improve justice by considering the therapeutic and anti-therapeutic consequences that flow from substantive rules, legal procedures, or the behavior of legal actors." 131 They are designed to deal holistically ${ }^{132}$ with people arrested (usually, but not exclusively, for nonviolent misdemeanors) ${ }^{133}$ when mental illness, rather than criminality, appears to be

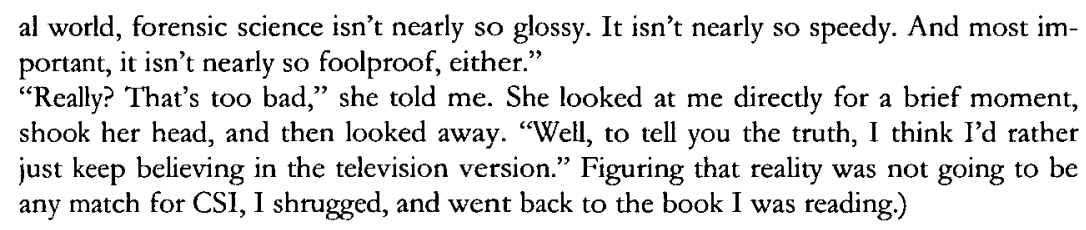

al world, forensic science isn't nearly so glossy. It isn't nearly so speedy. And most important, it isn't nearly so foolptoof, either."

"Really? That's too bad," she told me. She looked at me directly for a brief moment, shook her head, and then looked away. "Well, to tell you the truth, I think I'd rather just keep believing in the television version." Figuring that reality was not going to be any match for CSI, I shrugged, and went back to the book I was reading.) Id.

129. See generally Perlin, Gates of Eden, supra note 107; Michael L. Perlin, "The Judge, He Cast His Robe Aside": Mental Health Courts, Dignity and Due Process, 3 J. Mint. Health L. \& POL'Y (forthcoming 2013).

130. Problem-solving courts grew out of an interdisciplinary approach to address the underlying problem, not just the symptoms, of "substance abuse, domestic violence, child abuse, mental illness, and certain kinds of criminality." See generally Bruce J. Winick, Therapeutic Jurisprudence and Problem Solving Courts, 30 FordhAm URB. L.J. 1055, 1060 (2003). For overviews, see generally Michael Dorf \& Jeffrey Fagan, Problem-Solving Courts: From Innovation to Institutionalization, 40 AM. CrIM. L. RlEv. 1501 (2003) (providing an overview of problem-solving courts). See also Jeffrey Fagan \& Victoria Malkin, Theorizing Community Justice througb Community Courts, 30 FordhAм URb. L.J. 897-98 (2003).

131. Nancy Wolff, Courts as Therapeutic Agents: Thinking Past the Novelty of Mental Health Courts, 30 J. Am. ACAD. Psychiatry L. 431, 431 (2002). See also Randal Fritzler, How One Misdemeanor Mental Health Court Incorporates Therapeutic Jurisprudence, Preventive I an, and Restorative Justice, in managimint and administration of Corrictional Hizalth Carli: Policy, Practici, ADMINISTRATION 14-1, 14-3 (Jacqueline Moore ed., 2003) ("PT] he fundamental principle underlying therapeutic jurisprudence is the selection of options that promote health and are consistent with the values of the legal system.').

132. Shauhin Talesh, Mental Health Court Judges as Dynamic Risk Managers: A New Conceptual ization of the Role of Judges, 57 DisPui. L. REv. 93, 112 (2007).

133. See Johnston, supra note 50, at 521 (discussing the trend towards the expansion of predicate case jurisdiction to include felonies, include violent felonies). See, e.g., Andrew Wasicek, Mental Illness and Crime: Envisioning a Public Health Strategy and Reimaging Mental Health Courts, 48 Crim. L. Bull. 106, 135 (2012):

Mental health courts should accept violent felonies because it is morally unsound to punish criminal behavior that is mainly a product of mental disease. With appropriate eligibility criteria, the new mental health court model would encapsulate persons who are not shielded by the insanity defense - especially persons from post-Jones v. U.S., 463 U.S. 354 (1983) . . Japproving stringent statutory measures governing releases of persons found not guilty by reason of insanity, see 4 MichaEI. L. Perlin, Mental. 
the precipitating reason for the behavior in question. ${ }^{134}$ The mental health court judge ${ }^{135}$ seeks to divert the individual from the criminal court in exchange for an agreement to participate in community treatment, ${ }^{136}$ and to "help participants avoid future criminal court involvement."137

What impact does this have on the question at hand? Judge Ginger Lerner Wren is explicit: "The innovation of mental health courts was a direct judicial response to the trend known as the "criminalization of the mentally ill."'138 I agree with the late Professor Bruce Winick that, in this specific context, problem-solving courts and therapeutic jurisprudence "can do much to transform law into an instrument of healing for both the individual and the community,"139 and with Janet York and her colleagues that "therapeutic jurisprudence in the court system reduces stigmatization of addicts and shifts the court's focus from criminalization . . . to treatment."140 The therapeutic jurisprudence-basis of mental health courts is a perfect antidote to so much of both the actual criminalization of persons with mental illness and the criminalization "debate." One of the great values of the "Memphis program" discussed earlier is how it has "resulted in reduced injuries and arrests and in-

Disability Law: Civil. AND Criminal, at 290-98 (2d ed. 2002)] . . era — but should still be held blameless.

134. See generally Susan Stefan \& Bruce Winick, A Dialogue on Mental Health Courts, 11 PsYChOL. PUB. POI.'Y \& L. 507, 511 (2005). See also generally Fritzler, supra note 131; Arthur Lurigio et al., Therapeutic Jurisprudence in Action: Specialized Courts for the Mentally Ill, 84 JUDICATURI: 184, 186 (2001); John Petrila et al., Preliminary Observations from an Evaluation of the Broward County Mental Health Court, 37 CT. Rivv. 14, 14 (2002); Ian Freckelton, Mental Health Review Tribunal Decision-making: A Therapeutic Jurisprudence Lens, 10 PsYCHIATRY, PsYCHOL. \& L. 44, 55-56 (2003).

135. Julie B. Raines \& Glenn T. Laws, Mental Health Court Survey, 45 CRıM. L. Bul... 627, 632 (2009) ("Judges are the most common referral source of participants into diversion programs (100\% of survey respondents), with mental health personnel ( $93 \%$ of respondents) coming in second, and attorneys (90\% of respondents) coming in a close third. For those agencies that chose the "other" category, they indicated that referrals could come from families, service providers, law enforcement personnel, community agencies, and parole officers.").

136. Marjorie A. Silver, lawyering and Its Discontents: Reclaiming Meaning in the Practice of I aw, 19 Touro L. Risv. 773, 803 (2004). See also Talesh, supra note 132, at 110; Camille Nelson, Racializing Disability, Disabling Race: Policing Race and Mental Status, 15 Bi:RK1:LIYY J. CRIM. L. 1, 2 (2010) (on the necessity of diversion); John Cummings, The Cost of Crayy: How Therapeutic Jurisprudence and Mental Health Courts I ower Incarceration Costs, Reduce Recidivism, and Improve Public Safeey, 56 LOY. L. Risv. 279, 306 (2010) (discussing mental health courts' "palpable results"). On the question of whether this diversion is swifter than traditional court processing, see Allison Redlich et al., Is Diversion Swift: Comparing Mental Health Court and Traditional Criminal Justice Processing, 39 CRIM. JUST. \& BiHAV 1, 2-3 (2012) (although diversion may not be swifter than traditional court processing, that may be less important than the fact of diversion itself).

137. Kirk Kimber, Mental Health Courts - Idabo's Best Kept Secret, 45 IDAHO L. RI:v. 249, 270 (2008). See also Brenda Desmond \& Paul Lenz, Mental Health Courts: An Effective Way of Treating Offenders with Serious Mental Illiness, 34 MiNTAI \& PhYSICAL. DISABILITY L. RIiP. 525, 526 (2010).

138. Wren, supra note 51 , at 586 .

139. Winick, supra note 130 , at 1090.

140. Janet York et al., Family Drug Treatment Courts and Social Determinants of Health, 50 FAM. CT. RI:V. 137, 141 (2012). 
creased diversion of mentally ill individuals into treatment programs. ${ }^{141}$ There is a robust literature describing diversion programs that have "worked," meaning that the individuals involved have been afforded treatment and been able to avoid all of the negative consequences of prison incarceration. ${ }^{142}$ Such programs clearly reflect the tenets of therapeutic jurisprudence.

Also, in such programs, the individual subject to the court proceeding is far more likely to feel that he has a "voice." Recall Professor Ronner's "three V's" - voice, voluntariness and validation ${ }^{143}$ - and consider them in the context of the research that has been done about the Broward County Mental Health Court. That research tells us that defendants who appear in that court report a higher score on a "dignity" scale (and a lower score on a "perceived coercion" scale) 144 than any group of criminal defendants who have ever been studied. ${ }^{145}$ In short, the actual, real life experiences of the litigants in cases before Judge Wren - the presiding judge of the Broward Court ${ }^{146}$ demonstrates that at least one mental health court can be a non-coercive, dignified experience that provides procedural justice and therapeutic jurisprudence to those before it. ${ }^{147}$

We also must consider the question of the adequacy of counsel appointed to represent the defendants who are the subject of consideration here. ${ }^{148}$ What about counsel? I have written often about the scandalous lack of effective counsel made available to persons with mental disabilities in the civil

141. Calloway, supra note 37 , at 359 n. 77.

142. See SLATE \& JOHNSON, supra note 14, at 196-200 (discussing programs).

143. See Ronner, supra note 123 , at 627.

144. See Bruce Winick, A Therapeutic Jurisprudence Approach to Dealing with Coercion in the Mental Health System, 15 PSYCHIATRY, PSYCHOL. \& L. 25 (2008) (discussing the role of therapeutic jurisprudence in dealing with coercion in the mental health court process).

145. See Norman G. Poythress et al., Perceived Coercion and Procedural Justice in the Broward Mental Healtb Court, 25 INT'l.J.L. \& Psychiatry 517, 529-30 (2002).

146. See Wren, supra note 51, at 589.

147. See Judith Kaye, Lecture, 81 ST. JOHN's L. Rev. 743, 748 (2007) (“MMental health courts, which ... divert defendants from jail to treatment, reconnect them, where possible, with family and friends who care whether they live or die . . . and restore their greatest loss--their sense of human dignity."); Hafemeister, supra note 47, at 201-02 ("[P|rocedural justice is a key to the success of mental health courts."). 'Judge Wren's is not the only court to reflect these dignitarian values. See also Matthew J. D'Emic, The Promise of Mental Health Courts, 22 Crum. JUST. 24 (2007) (discussing other courts besides Broward County mental health Court which reflect these dignitarian values); PISRI.IN, supra note 127, at 63-78 (discussing mental health courts).

On the important related issue of the impact of such courts on racial and ethnic minorities, see Robert V. Wolf, Race, Bias, and Problem-Solving Courts, 21 NAT'l. Bl.ACK L.J. 27, 4647 (2009) (research by National Center for State Courts reveals that African-Americans and Latinos show more support for practices and procedures promoted by problem-solving courts than do whites). On the impact of such courts on immigrants, see generally Alina Das, Immigrants and Problem-Solving Courts, 33 CRIM. JUST. REV. 308 (2008).

148. See generally PERIIN, supra note 127. 
commitment and criminal justice processes. ${ }^{149}$ What is the quality of counsel available to litigants in mental health courts?

Dr. Steven Erickson and his colleagues have expressed concern "as to whether defendants in mental health courts receive adequate representation by their attorneys." 150 Terry Carney characterizes the assumption that adequate counsel will be present at hearings to guarantee liberty values as a "false hope."151

Henry Dlugacz and Christopher Wimmer summarize the salient issues:

It is not reasonable to expect a client to repose trust in an attorney unless she is confident that he is acting in accordance with her wishes. The client with mental illness may already doubt the attorney's loyalty. This risk is exacerbated when the attorney is appointed by the court. The client may wonder whether the attorney has been assigned in order to zealously represent her, or instead to facilitate her processing through the legal system .... There are thus strong personal disincentives to thorough preparation, even for the committed attorney .... There are also institutional pressures: The attorney who depends on the goodwill of others in the system (e.g., judges, state attorneys, or prosecutors) may pull his punches, even unwittingly, in order to retain credibility for future interactions (which he would put to use for his future clients). Judges want cases resolved. ${ }^{152}$

Some solutions have been offered. Bruce Winick as argued that "lawyers should adequately counsel their clients about the advantages and disadvantages of accepting diversion to mental health court .... As a result, judges and defense counsel in mental health courts should ensure that defendants

149. See Michael L. Perlin, "T Might Need a Good I anyer, Could Be Your Funeral, My Trial": A Glabal Perspective on the Right to Counsel in Civil Commitment Cases, and Its Implications for Clinical I egal Education, 28 WASH. U. J. L. \& SOC'I. POI.' 241, 241 (2008) ("If there has been any constant in modern mental disability law in its thirty-five-year history, it is the near-universal reality that counsel assigned to represent individuals at involuntary civil commitment cases is likely to be ineffective."); Michael L. Perlin, "Ihe Executioner's Face Is Always Well-Hidden": The Role of Counsel and the Courts in Determining Wbo Dies, 41 N.Y.L. SCH. L. Rivv. 201, 207-08 (1996) ("Nearly twenty years ago, when surveying the availability of counsel to mentally disabled litigants, President Carter's Commission on Mental Health noted the frequently substandard level of representation made available to mentally disabled criminal defendants. Nothing that has happened in the past two decades has been a palliative for this problem.”). See generally MICHAlí. L. PlikI IN, Mintal. Disability and thli Diath Pignalty: Thli Shame of thi: Criminal. Justice: SYSTI:M 123-39 (2013).

150. Steven Erickson et al, Variations in Mental Health Courts: Challenges, Opportunities, and a Call for Caution, 42 COMm. MinTaI. Hisal.TH J. 335, 340 (2006).

151. Terry Carney, The Mental Health Service Crisis of Neoliberalism - An Antipodean Perspective, 31 INT'I. J. L. \& PSYCHIATRY 101, 111 (2008).

152. Henry A. Dlugacz \& Christopher Wimmer, 'The Ethics of Representing Clients with I imited Competency in Guardianship Proceedings, 4 ST. LOUIS U. J. HıAI.TH L. \& POL'Y 331, 353-54 (2011). 
receive dignity and respect, are given a sense of voice and validation." 153 Turning to the legal education clinical context, David Wexler has suggested that students might "consider the kind of dialogue a lawyer might have with a client about the pros and cons of opting into a [drug treatment court] or mental health court." 154 It is essential that counsel has "a background in mental health issues and in communicating with individuals who may be in crisis." 155

One of the critical functions of counsel is to "protect the dignity and autonomy of a person on trial."156 Fair process norms such as the right to counsel "operate as substantive and procedural restraints on state power to ensure that the individual suspect is treated with dignity and respect" 157 Recently, in an article about the significance of trained counsel in efforts to effectuate social change in nations with developing economies in Asia, I said this: "There is no question that one of the most critical aspects of law reform is the presence of dedicated and knowledgeable counsel. Without the assignment of such counsel, meaningful and ameliorative change is almost impossible to achieve."158

I believe that precisely the same argument can be made with regard to the issues under discussion here.

Also, consider here the role of judges. ${ }^{159}$ Judge Michael King has written eloquently about the need for judges to become experts in the interpersonal aspects of judging, noting that, depending on the circumstances, judging may require "particular listening and communication skills, the expression of empathy, the use of techniques of persuasion or motivational interviewing, the use of techniques to settle child witnesses and collaborative problem-solving

153. Stefan \& Winick, supra note 134, at 510-11, 520 (comments by Professor Winick).

154. David B. Wexler, Therapeutic Jurisprudence and the Rehabilitative Role of the Criminal Defense I anyer, 17 ST. 'ThOMAS L. REv. 743, 750 (2005). On dialogues that defense lawyers might have with their clients in incompetency status or insanity defense cases, see Perlin, supra note 90.

155. Tammy Seltzer, A Misguided Attempt to Address the Criminal Justice System's Unfair Treatment of People with Mental Illness, 11 PsyCHOL. PuB. POL'Y \& L. 570,576 (2005). See also M. Carmela Epright, Coercing Future Freedom: Consent and Capacities for Autonomous Choice, 38 J.L. MiD. \& ETHICS 799, 801 (2010) ("Ideally, in mental health courts all courtroom personnel (i.e., judge, prosecutor, defense counsel and other relevant professionals) have experience and training in mental health issues and available community resources.").

156. Jones v. Barnes, 463 U.S. 745, 759 (1983) (Brennan, J., dissenting). See also, e.g., Philip Halpern, Government Intrusion into the Attomey-Client Relationship: An Interest Analysis of Rights and Remedies, 32 BurF. L. Rivv. 127, 172 (1983) ("The right to counsel embraces two separate jnterests: reliable and fair determinations in criminal proceedings, and treatment of defendants with dignity and respect regardless of the effect on the outcome of criminal proceedings.').

157. Peter Arenella, Retbinking the Functions of Criminal Procedure: 'The Warren and Burger Courts' Competing Ideologies, 72 GEO. L.J. 185, 200 (1983).

158. Michael L. Perlin, Online Distance I egal Education as an Agent of Social Change, 24 PAC. McGiorgı: Global Bus. \& Dev. L.J. 95, 104 (2011).

159. See Perlin, Veterans' Courts, supra note 108. 
techniques." 160 Certainly, the need for these skills is intensified in cases involving the population in question.

In discussing the question of the link between mental illness and criminal behavior, Professor Jennifer Skeem and her colleagues recommended three policy priorities: (1) identifying offenders for whom mental illness directly causes criminal behavior; (2) identifying "evidence-based corrections," including, isolating "the ingredients of existing programs that reduce recidivism;" and (3) assessing and addressing system bias, whether this bias is "motivated by fear or paternalism."161 I believe all three of these are important goals that we should seek to implement. Her third goal - the focus on bias, partially motivated by fear - is at the core of the sanist and pretextual behavior that controls the entire mental health system, especially when mental health and criminal justice issues are intertwined. ${ }^{162} \mathrm{I}$ believe that, until we face this issue, our efforts at remediation are doomed to failure. However, if we do - as I think we must - use therapeutic jurisprudence as a mechanism to "expose pretextuality and strip bare the law's sanist façade," 163 I believe then, and only then, will we be able to make authentic ameliorative change.

My title, again, comes from Bob Dylan's underappreciated song, Political World. The lines that immediately follow the one that I use in the title are these:

It [referring to wisdom] rots in a cell, is misguided as hell

Leaving no one to pick up a trail. ${ }^{164}$

The world that Dylan describes in this song is, per Oliver Trager, a "cold and incomprehensible place." 165 So is a prison stay for so many persons with mental disabilities. It is time we, again, with a nod to a different Dylan song, "strike another match [and] go start anew;"166 it is the least that we can do.

160. Michael S. King, Realising the Potential of Judging, 37 MONASH L. Riv. 171, 172 (2011).

161. Skeem et al., supra note 42 , at $120-22$.

162. Sanism is an irrational prejudice of the same quality and character of other irrational prejudices that cause, and are reflected in, prevailing social attitudes of racism, sexism, homophobia, and ethric bigotry. It permeates mental disability law, affecting all participants in the mental disability law system: litigants, fact-finders, counsel, and expert and lay witnesses. Its corrosive effects have warped mental disability law jurisprudence. See, e.g., Perlin, Expecting Rain, supra note 111 , at 487,506 . See generally PriRLIN, supra note 78 . On pretextuality, see generally, supra note 79.

163. Perlin, supra note 117, at 544; Michael L. Perlin, "They Keep It All Hid:": The Ghettoization of Mental Disability I aw and Its Implications for Iegal Education, 54 ST. LoUIS U. L. J. 857, 875 (2010).

164. Bob Dylan, Political World, on OH Mercy (Sony Music Entertainment Inc. 1989).

165. TRAGIR, supra note 25 , at 493.

166. Bob Dylan, It's All Over Now, Baby Blue, on BRINGing It Ai.l. BACK Home (Sony Music Entertainment Inc. 1965). 
$$
\text { . }
$$ 